\title{
ФУНКЦІОНУВАННЯ ЕЛЕМЕНТІВ ЛАТИНСЬКОЇ МОВИ У СУЧАСНОМУ КУЛЬТУРНОМУ СЕРЕДОВИЩІ УКРАЇНИ ТА СВІТУ
}

У статті зроблено огляд наукових джерел, в яких викладені проблеми входження та функиіонування запозиченої лексики латинського й греко-латинського походження в культурний простір України. Проаналізовано стан дослідження латинізмів в українській мові на різних хронологічних зрізах. Виявлено сфери функиіонування елементів латинської мови в сучасному світовому культурному середовищі.

Міжмовна взаємодія постійно привертає увагу лінгвістів, а прочес запозичення іншомовної лексики, зокрема латинського походження, трунтовно описаний у наукових праиях у різних аспектах. Проте на часі виникає необхідність вивчення латинізмів у сучасному дискурсі.

Відомо, що протягом тривалого часу латина була засобом комунікації для народів Свропи й відігравала важливу роль в їхньому культурному розвитку. У результаті латинська мова є джерелом поповнення наукової термінології всіх європейських мов; складає основу професійної термінології в медицині, юриспруденції, ботаніџі тощо; с міжнародною мовою науки; традиійно залишається мовою католиџької релігії (офіційно використовусться Ватиканом).

В українській мові латина слугувала засобом інтелектуалізаиії упродовж XIII-XVII та до початку XX століття та існувала в основному в галузі науки, освіти й релігійної сфери. Наприкінці XX-початку XXI століття характерне входження великої кількості слів латинського походження в сучасну украйнську мову.

Новітні напрями функиіонування мовних елементів латини в сучасному суспільстві з'являються в кіниі XX - на початку XXI століття. Це - рухи за використання латини, всесвітня мережа Інтернет (електронні бібліотеки, комп'ютерна лінгводидактика, форуми, сайти, журнали в режимі опline), комікси, література, радіостаниї̈, ще віщають латиною тощо.

Можна зазначити, що в наш час Latinitas переживає певне «відродження». Посилення тенденцій до ії застосування в сучасних мовах дозволяє говорити про важливу роль класичної мови як культурного й комунікативного феномену, а сфери ії функиіонування викликають науковий інтерес.

Ключові слова: запозичення, латинізми, новітні сфери функціонування, сучасний дискурс.

Hanna PATLATA, orcid.org/0000-0001-7877-2850 Postgraduate Student at the Department of Translation, Applied and General Linguistics Volodymyr Vynnychenko Central Ukrainian State Pedagogical University (Kropyvnytskyi,Ukraine) patlataav@ukr.net

\section{FUNCTIONING OF LATIN ELEMENTS IN MODERN CULTURAL ENVIRONMENT OF UKRAINE AND THE WORLD}

In the article scientific works have been studied and issues of adopting and functioning of borrowings of Latin as well as Greek and Latin origin in Ukrainian cultural environment have been highlighted. The research findings of Latinisms in the Ukrainian language in different chronological segments have been analyzed. The spheres of Latin elements' functioning in the world's cultural environment (the end of XX century, the beginning of XXI century) have been determined.

Translingual interaction always attracts the linguists' attention, and the process of foreign language borrowing, notably of Latin origin, is fully described in scientific works in different aspects. However, at present there is a necessity to study latinisms in modern discourse.

It is a common knowledge that Latin has been a means of communication for European peoples and played a very important role in their development for a long time. In the result the Latin language has become the source of harvesting scientific terminology from all the European languages; it is the basis of professional terminology in medicine, law, botany, etc.; it is an international language of science; and it is traditionally the language of Catholicism (it is officially spoken in Vatican). 
During XIII-XVII centuries and to the early XX century Latin served as a means of intellectualization and was used generally in the fields of science, education and religion. The late XX century and the early XXI century is characterized by adoption of a big number of Latin-derived words into modern Ukrainian.

New tendencies in the functioning of Latin elements in modern society appeared at the beginning of the XXI century. These are the actions for the usage of Latin, Internet World Wide Web (electronic libraries, computer linguodidactics, forums, sites, online journals), comics, literature and others.

Intensification of tendencies to use Lain in modern languages allows stating its significant role as a cultural and communicative phenomenon. It can be noted that in the XXI century the Latin language experiences a certain "rebirth", and spheres of its functioning arouse scientific interest.

Key words: borrowings, latinisms, the newest spheres of functioning, modern discourse.

Постановка проблеми.Проблема мовних запозичень посідає важливе місце в лінгвістиці й, на думку дослідників, заслуговує на особливу увагу. Міжмовні контакти в різних аспектах протягом багатьох століть викликають постійний інтерес науковців, а проблема вивчення українсько-іншомовних взаємин у різних дискурсах і різних хронологічних зрізах $\epsilon$ актуальною і для сучасної лінгвістики. Як відомо, одну з найчисленніших груп запозичень в європейських мовах складають запозичення 3 класичних мов, зокрема 3 латинської, так звані «латинізми», які займають значне місце в інтернаціональному словниковому фонді.

Треба зазначити, що поняття «лексичний латинізм» ще не отримало загальноприйнятого визначення. У науковій літературі використовуються терміни «латинізм», «латиномовне запозичення», «греко-латинізм», «греко-латинське запозичення», «латинське запозичення» тощо. На думку дослідників, причиною слугує проблема встановлення джерела запозичень. До того ж вони стверджують, що дефініція терміну «<...> залежить від різних методологічних настанов авторів і глибини класифікації запозичень.» (Паньків, 2011: 387). Найчастіше «латинізм» трактують як слово чи зворот, запозичене $з$ латинської мови й таке, що сприймається як чужорідний елемент (Паньків, 2011), такого визначення будемо притримуватись у нашому огляді й ми.

Актуальність огляду зумовлена необхідністю дослідження латинізмів в українській мові в сучасному дискурсі.

Аналіз досліджень. Як уже зазначалось раніше, проблема запозичення іншомовної лексики, зокрема латинського походження, протягом тривалого періоду привертала увагу українських і зарубіжних дослідників і була грунтовно описана в наукових працях у різних аспектах.

У зарубіжній лінгвістиці можна виділити праці А. Брюкнера, О. Булики, Г. Кайперта, Е. Кендельської, Д. Мошинської, Г. Рибіцької, Я. Сафаревіча й інших, в яких досліджено екстралінгвальні аспекти латинських запозичень.

У дисертаційних дослідженнях С. Гриценко, Ю. Цимбалюк, В. Титаренко подано аналіз входження латинської лексики в українську мову.
Етапи й ступені адаптації чужомовізмів / латинізмів досліджували Л. Архипенко, С. Семчинський, О. Стишов; особливості функціонування запозичень / латинських запозичень у лексикосемантичній системі мови-реципієнта вивчали О. Лисенко, У. Мрозіцька (Паньків), В. Роман; на класифікації запозиченої лексики, в тому числі й латинського походження, за структурно-семантичними ознаками акцентувала В. Сімонок.

Крім того, науковцями була досліджена роль використання сучасною термінологією інтернаціональних терміноелементів класичного походження (І. Вакулик).

Одним із вирішальних етапів у розвитку української мови й культури $є$ період XVI-XVII століть. Дослідниками В. Титаренко, С. Гриценко й іншими проаналізовано різні тематичні групи лексики, в тому числі й латинського походження, які ввійшли в нашу мову протягом такого історичного проміжку.

Неабиякий науковий інтерес представляють описи літературних пам'яток різних стилів і коментарі до них: офіційно-ділового, конфесійного, публіцистичного, епістолярного (I. Черкес, Г. Клімчук та інші).

Об'єктивний стан сучасної науки й освіти в Україні викликає потребу збирати, систематизувати й видавати у відповідних словниках все лексичне (термінологічне) багатство; давати тлумачення нових слів і значень, сприяти поповненню національного лексичного фонду й розвитку української літературної мови. Цей вид видань посідає чільне місце в системі інформаційного забезпечення будь-якої галузі науки.

Лінгвістичні словники $є$ одними з основних джерел досліджень запозиченої лексики. Це словники іншомовних слів, етимологічні словники української та латинської мов; термінологічні (юридичні, теологічні, економічні, медичні й інші) словники й енциклопедії; двомовні й тримовні перекладні словники; словники крилатих висловів тощо. Їх авторами $є$ науковці 3. Кузеля, М. Чайковский, 3. Пиптенко, П. Кіянець, О. Скопненко, Т. Цимбалюк, І. Гнатишена, Т. Кияк, П. Мовчан і багато інших. 
Метою нашої статті є огляд наукових джерел, які розкривають особливості функціонування лексики латинського й греко-латинського походження в українській мові на різних хронологічних зрізах.

Виклад основного матеріалу. Відомо, що латинська мова й антична культура $\epsilon$ основою сучасної європейської культури. Велика кількість слів латинського походження запозичені багатьма європейськими мовами, в тому числі й українською. Протягом століть латина слугувала засобом комунікації для народів Свропи й є специфічною мовою науки, освіти, медицини, філософії, юриспруденції та інших сфер життя та діяльності людини. Крім того, на іiі основі формувались термінології більшості європейських мов. Натепер латинізми, запозичені безпосередньо з латинської або через посередництво інших романських мов, займають значне місце в інтернаціональному словниковому фонді.

Як вже було сказано, антична традиція в європейській культурі викликає постійний інтерес науковців і $є$ предметом грунтовних досліджень не тільки в галузі мовознавства, а й літератури, науки, мистецтва на різних історичних етапах, зокрема на сучасному. До того ж латинська мова протягом тривалого часу відігравала важливу роль у культурному розвитку країн Західної Свропи.

Загальновідомий і той факт, що за часів Середньовіччя латина стала джерелом поповнення наукових термінологій усіх європейських мов. Лексика грецької та латинської етимології слугувала основою «наукової мови», а в ботаніці, зоології, юриспруденції та медицині склала основу професійної термінології, яка згодом стала інтернаціональною. У культурі нашого часу латинська мова офіційно є міжнародною мовою науки. Разом із тим вона традиційно залишається мовою католицької релігії та офіційно використовується Ватиканом.

Уперше в українській мові латинізми було зафіксовано в X-XI ст., однак основна їх частина була засвоєна в період XVI-XVII ст.

Налагодження торговельно-економічних зв'язків із західними сусідами (чехами, поляками, угорцями) в XIII - першій половині XIV ст. зумовлюють появу латиномовних дипломатичних документів князівських дворів із Галичини й Волині (Шевченко-Савчинська, Балашов, 2012).

На думку В. Миронової, латина періоду XIVXVI ст. використовувалась лише в деяких (трьох) сферах людської діяльності «<... латинська мова 3 XIV ст. на території Галицької Русі, а з XVI ст. на Волині й Наддніпрянщині стає мовою трьох сфер вживання: міській - магістратській сфері <..>, церковній сфері <..>, «земській», тобто шляхет- ській сфері публічного побуту <...>» (Миронова, 2009: 201-202).

Щодо періоду XVI ст., В. Сімонок зазначає, що запозичення з інших мов відбуваються через посилення зв' язків з Свропою, де здобували освіту багато українських діячів культури й православного слов'янського світу. В університетах Свропи навчались Мелетій Смотрицький, Петро Могила, Феофан Прокопович і багато інших. Дослідниця вважає, що запозичення зазначеного періоду були привілеєм невеликого кола інтелектуальної еліти тогочасного суспільства, «<...> проникали в українську мову через мову привілейованих соціальних груп і були мало поширені в народній розмовній мові» (Сімонок, 2014: 252).

Період XVI-XVII ст. характеризується інтенсивним на той час розвитком науки й шкільництва: в різних регіонах України створюються братські школи, перша 3 яких виникла у Львові; засновуються потужні освітні осередки: перша школа вищого ступеня Острозька греко-слов'янськолатинська школа (1576 рік) та перший вищий навчальний заклад України - Києво-Могилянська колегія (пізніше, у XVIII ст. - Києво-Могилянська Академія) (Вакулик, 2016). Мовою викладання в навчальних закладах переважно була латинська. Ці події мали велике значення для становлення вищої освіти в країні. Сприяла поширенню латинської мови й друкарська справа.

Можна відзначити, що вплив латинської мови на культурне життя в Україні XVI-XVII ст. був досить сильним. Вона залишалась мовою релігії, освіти, дипломатії та філософії - мовою вузького кола освічених людей. У своїй праці автори Л. Шевченко-Савчинська й К. Балашов зауважують, що латина XVII ст. виходить із розмовного вжитку «< .. > У XVII ж столітті вона - друга рідна мова для українських інтелектуалів < ..>» (Шевченко-Савчинська, Балашов, 2012).

У XVIII ст. українці, які закінчили медичний факультет Страсбурзького університету, відігравали важливу роль у створенні системи освіти й розвитку наукової думки в Україні. За їх участі була створена Києво-Могилянська академія. Багато письменників цього періоду писали свої твори латинською мовою. Нею досконало володіли Петро Конашевич-Сагайдачний, Юрій Дрогобич, Іван Домбровський, Григорій Сковорода, Феофан Прокопович, Стефан Яворський і багато інших діячів вітчизняної історії та культури. Латинською мовою написані листи Богдана Хмельницького, конституція Пилипа Орлика, Великий требник Петра Могили й інші важливі для нашої історії документи (Сімонок, 2014). 
Якщо говорити про період XIX-XX ст., на прикладі мовного досвіду української інтелігенції дослідниця I. Черкез відзначає, що історичні обставини функціонування української мови стали причиною існування двох варіантів літературної мови - східного й західного. Учасники мовних дискусій, що відбулися в українському культурному середовищі «<...> у спробах з'ясувати доцільність вживання іншомовних елементів в українській літературній мові $<\ldots>$ поділилися на два табори. Представники західноукраїнської інтелектуальної еліти висловлювалися за помірковане ставлення до цих мовних засобів, натомість у середовищі східноукраїнської інтелігенції це ставлення було зазвичай негативним <..>». Дослідниця підкреслює, що «<..> в розмовному вжитку представників інтелігенції всіх українських земель XIX - початку XX ст. перебувало чимало іншомовних елементів, вагому частку яких становили латинізми» (Черкез, 2006: 42-43).

Про використання лексики латинського походження свідчать результати досліджень писемних пам'яток різних стилістичних жанрів такого хронологічного відрізка. Наприклад, епістолярні тексти й щоденникові записи відомих українських письменників громадсько-політичних діячів, публіцистів, вчених, діячів культури й мистецтва стали джерелом вивчення багатьох вчених. Це листи М. Драгоманова, М. Грушевського, I. Франка, Л. Українки, О. Кобилянської, Б. Лепкого, щоденники $Є$. Чикаленка, С. Єфремова й інші. Латинізми, зафіксовані в текстах, охоплюють широкий тематичний спектр: лексика, що обслуговує сферу ділових стосунків, пов'язаних iз суспільно-політичною та громадською діяльністю; лексика, що характеризувала освітньонаукову сферу, лексика галузі судочинства, економічна лексика тощо (Черкез, 2006, Клімчук, 2010).

До того ж у другій половині XIX ст. в Україні спостерігається процес інтернаціоналізації мови науки, що сприяло зростанню ролі класичних мов як джерела для утворення нових та уніфікації вже наявних наукових термінів.

Розглянемо сфери й особливості функціонування елементів латини в Україні й світі із середини XX та на початку XXI ст.

Можна відзначити, що, незважаючи на значне звуження, сфера вживання мовних елементів латини й в наш час $є$ досить широкою. Вона продовжує залишатись важливим культурним явищем сучасного світу. В умовах сьогодення в європейській культурі латина живе своїм особливим життям, а в культурі й мові нашої країни вона посідає своє осібне місце.
У сучасному суспільстві міжкультурна комунікація розвивається практично в усіх сферах людської діяльності, тому культурно-історична спадщина античності слугує основою для формування істинно гуманної особистості.

Однією 3 вагомих проблем сучасного світу $\epsilon$ ослаблення духовних цінностей, i шляхи ії розв'язання вбачаються лише в умовах освіти, тому що саме в освітньому середовищі закладаються норми й правила поведінки, традиції тощо.

Як уже підкреслювалося вище, до початку $\mathrm{XX}$ ст. латина майже вийшла 3 ужитку. Відродження інтересу до стародавніх мов в Україні розпочалось тільки наприкінці XX ст., і протягом декількох останніх десятиліть можна констатувати відродження викладання латинської мови в навчальних закладах країни. Дисципліна була включена до освітніх програм середніх навчальних закладів (гімназій, ліцеїв тощо), інтенсифікувався процес впровадження латинської мови у вищі навчальні заклади.

Натепер латинську мову, античну літературу й міфологію вивчають студенти не тільки філологічних, а й медичних, юридичних, ветеринарних, агротехнічних та інших спеціальностей вищих навчальних закладів. Для того, щоб повною мірою розуміти професійні терміни (як повнозначні слова, так і терміноелементи латинського або греко-латинського походження) та засвоювати їх, вивчення лексики цих давніх мов необхідне: cranium - череп (медична (анатомічна) термінологія); audientia - судовий розгляд (юридична); Laurus nobilis - лавр благородний (ботанічна); Hirundo - ластівка (зоологічна) тощо.

Щодо використання латинської мови в сучасній науці, відомо, що в цілому ряді наукових галузей користуються латинськими термінами - це математика, фізика, біологія, зоологія, хімія, філологія, астрономія та інші. До того ж, як вже було зазначено, це міжнародна мова медичної, ботанічної, ветеринарної та юридичної термінологій.

Ще однією зі сфер вживання латинської мови в наш час $є$ релігія. Центром живої латини являється Ватикан і Римсько-католицька церква в цілому. Latinitas стала сьомою офіційною мовою сайту, на якому представлені тексти в розділах «Біблія», «Кодекс канонічного права», «Другий Ватиканський собор» та інші.

Вищезазначені сфери використання латинської мови можна віднести до так званих «класичних», які існували протягом тривалого часу, але на початку XXI ст. з'являються нові напрями функціонування та значно посилюються тенденції до застосування мовних елементів латини в сучасному суспільстві. 
До нашої країни ці течії приходять із Заходу, де на противагу пострадянським країнам в освітніх закладах ніколи не відмовлялись від античної традиції.

На початку XX ст. у деяких країнах Свропи й Південної Америки з'являються рухи за використання латини як спроби культурного відродження на основі античних традицій. Одним із них є рух "Latinitas viva" («Жива латина»), метою якого $е$ прагнення досягти більш інтегрованої Свропи й вживання латинської мови як міжнародної мови науки. У багатьох країнах проходять конгреси живої латини: у Франції, Італії, Німеччині, Румунії та інших. Наприклад, у Німеччині створено товариство "Societas Latina", центр якого розташовується в Саарбрюкені, яке випускає журнал "Vox Latina" 3 періодичністю 5 разів на рік. Також у Німеччині щорічно проводяться так звані «Латинські тижні в Аменебург» (Аменебург - містечко біля Марбурга). Подібні рухи існують і в інших країнах світу.

Однією з новітніх сфер вживання латини, яка виникла наприкінці XX ст., є всесвітня мережа Інтернет. Ці ініціативи покликані популяризувати латинську мову й латинську культурну спадщину в сучасному суспільстві.

Найбільш значущим інформаційним електронним ресурсом 3 латиської мови й культури є одна 3 кращих електронних бібліотек, що має найбільшу базу даних латинських і грецьких матеріалів, Perseus Digital Library (Tufts University). Дві бази даних пропонує електронна бібліотека античної та біблійної літератури Musaios (DJ Dumont, RM Smith): TLG (Thesaurus Linguae Graecae: Greek Texts) i PHI5 (Latin Texts and Bible Versions); pecypc оригінальних античних і середньовічних латинських текстів представлений у The Latin Library (mac.com); частина проєкту Forum Romanum (D. Camden, Harvard) - Corpus Scriptorum Latinorum - містить цифрову бібліотеку, яка до того ж має зручну пошукову систему. Варто відзначити, що ці ресурси розраховані на користувачів, які вже мають базові знання з латини (Балалаєва, 2016).

Одним із сучасних та актуальних напрямів використання латини в мережі Інтернет $\mathrm{e}$ комп'ютерна лінгводидактика. Великою популярністю користуються електронні варіанти підручників і навчальних посібників для вищих навчальних закладів; відеоуроки викладачів латинської мови розміщені на каналі Youtube, що являє собою навчальні відеоматеріали багатьма мовами світу. Це свідчить про міжнародний інтерес до вивчення латині. Значно більше курсів латинської мови пропонується користувачам для вивчення в режимі онлайн.
Виникають в мережі й колективні форми вивчення мови - форуми любителів латини, учасники яких мають можливість спільно іiі вивчати й удосконалювати знання. До того ж існує чимало форумів, на яких обговорюється не тільки вивчення латинської мови й історії Рима, але і як мова спілкування використовується саме латина.

Присутні в Інтернеті й сайти, на яких можна читати журналилатинськоюмовоюв режимі online, що здебільшого орієнтовані на сучасну молодь.

Прикладом відмінного новинного сайту $\epsilon$ http://ephemeris.alcuinus.net/; сайт центру латинської мови в Європі http://www.centrumlatinitatis. org/ та багато інших. Існують подібні інформаційні ресурси й в Україні, наприклад: Pinax http://www.pinax.com.ua, «Медієвіст. Українська латиномовна література» http://www.medievist. org.ua. До того ж є латинська версія Google, a Wikipedia містить розділ на латині.

В Інтернеті й друкованих ЗМІ латину репрезентують 3 урахуванням інтересів сучасних молодих користувачів, зокрема у формі коміксів («Мертва мова», нім. - Tote Sprache, 2010 рік). Сучасні розробники комп'ютерних ігор також активно використовують латинську лексику для створення певної атмосфери таємничості у своїх проєктах.

Ще один напрям використання латини - це сучасна література. У збірнику "Vita Camena" зібрані вірші авторів із п'ятдесяти країн. Крім того, на латинську мову перекладена велика кількість сучасних книг, дитячих оповідань і казок, наприклад «Гаррі Поттер і філософський камінь» Дж.К. Роулінг, «Парфумер» П. Зюскінда, «Аліса в країні чудес» Л. Керрола тощо.

Вагомого значення набуває спроба відродження розмовної латинської мови, яку пропагує pyx "Latinitas viva" (про який вже йшлося вище).

Щодо введення сучасної латинської лексики, Ватиканом випущено словник, який має назву "Lexicon recentis Latinitatis" та існує в багатьох національних варіантах. Варто відзначити, що багато латинських неологізмів - це досить громіздкі описання, наприклад: «баскетбол» - follis canistrique ludus (дослівно: гра в м'яч і кошик). Популярністю користується книга Генрі Берда «Латинська на всі випадки життя», в якій робиться спроба підібрати латинські еквіваленти для повсякденних розмовних фраз.

Щодо популярності латинської мови, особливе поширення вона має у Фінляндії. Коли в 1999 р. країна головувала в Свросоюзі, вона створила свій представницький сайт, крім того, латиною віщає одна 3 фінських радіостанцій. 
Ще одним з'єднувальним фактором для країн Європи є гімн Євросоюзу, який теж написаний латинською мовою.

Очевидний і той факт, що спілкування між користувачами мережі Інтернет із різних країн було б неможливим без використання єдиної мови, якою натепер $є$ англійська. «Латинська як лінгва франка» потенційно надає величезні можливості, спробу оцінити рівень популярності латини як мови міжнародного спілкування.

Натепер знання латинської мови необхідне не тільки вченим. Багато латинських слів увійшло в українську мову - це міжнародна термінологічна лексика й слова, що ми вживаємо повсякденно. Важливим залишається практичне використання латини в повсякденному побуті. Наприклад, латинські скорочення, які загальноприйняті й легко розуміються в усьому світі: N.B. (Nota bene! Зверни увагу!); P.S. (Post scriptum Післямова) й багато інших.

У сучасних мовах, зокрема в українській, використовуються лаконічні й афористичні формулювання, які традиційно об’єднуються терміном «латинські крилаті вислови», що можна зустріти як у науковій, так і в художній літературі.

Латинська мова багата на такі вирази, основними предметними сферами яких є: афоризми життєвої мудрості (прислів'я, приказки тощо), вирази 3 області наукового знання (медицина, юриспруденція тощо), 3 літературних творів, висловлювання відомих історичних постатей, зобов'язані своій появі конкретній ситуації. Наприклад, Finis coronat opus («кінець - справі вінець»), De gustibus non est disputandum («про смаки не сперечаються»), Festina lente («поспі- шай, не поспішаючи») й інші. Їх функціональна роль полягає в посиленні виразності висловлювання, вони виступають як стилістичний засіб.

Висновки. Отже, латинська мова $\epsilon$ основною мовою європейської культури від античності до сучасності, яка внесла вагомі зміни в мови країн Європи й стала частиною їх термінологічного складу. Лаконізм і точність вираження зробили іiі основним джерелом утворення наукових термінів.

У результаті огляду вищезгаданих наукових джерел можна зазначити, що латина слугувала засобом інтелектуалізації української мови упродовж XIII-XV ст., а інтенсивніше з XVI-XVII та до початку XX ст. та існувала в основному в галузі науки, освіти й в релігійній сфері.

У наш час латинська мова продовжує функціонувати в різноманітних сферах сучасного суспільства, що дозволяє говорити про інтерес, який вона викликає. Latinitas iснує не тільки в різних галузях науки, в освіті, релігії, а й у повсякденному житті. Знайомство 3 класичною мовою та ії вивчення завдяки мережі Інтернет доступне для кожного, хто виявляє зацікавленість до іiі вивчення, а не лише для осіб, які мають відповідну освіту й певні знання. Навряд чи латинську мову варто називати «мертвою», навпаки, можна зазначити, що у XXI ст. вона переживає певне «відродження», а сфери іiі функціонування в сучасному світі викликають науковий інтерес.

На основі аналізу наукових джерел, які було досліджено, можна зазначити, що в сучасній лінгвістиці будуть актуальні наукові розвідки, які розглядатимуть функціонування латинізмів у сучасному дискурсі у функціональному й культурному аспектах.

\section{СПИСОК ВИКОРИСТАНИХ ДЖЕРЕЛ}

1. Балалаєва О. Ю. Проєктування електронних посібників з латинської мови для вищих аграрних навчальних закладів : дис. ...канд. пед. наук : 13.00.10 ; Київ. нац. ун-т. біоресур. і природокористув. Київ, 2016. 269 с.

2. Вакулик I. І. Латинська мова: шляхи проникнення у нові західноєвропейські мови. Науковий вісник Наџіонального університету біоресурсів і природокористування України. Сер. Філологічні науки. 2016. Вип. 257. С. 57-63.

3. Гриценко С. П. Динаміка лексикону української мови XVI-XVII ст. : дис. ...д-ра філ. наук : 10.02 .01 ; Київ. нац. ун-т. ім. Т. Шевченка. Київ, 2018. 1151 с.

4. Клімчук Г. П. Лексика латинського походження в публіцистиці М. Грушевського. Філологічні студії: Науковий вісник Криворізького державного педагогічного університету. 2010. Т. 4. С. 84-97.

5. Миронова В. М. Латина як дипломатична мова української еліти XVI-XVII ст. Studia Linguistica. 2009. Вип. 3. С. 200-204.

6. Паньків У. Л. Історичні джерела українських лексичних латинізмів. Studia Linguistica. 2011. Вип. 5. С. $386-391$.

7. Сімонок В. П. Запозичена лексика в українській мовній картині світу. Науковий вісник Міжнародного гуманітарного університету. Сер. Філологія. 2014. № 8. Т. 2. С. 250-254.

8. Шевченко-Савчинська Л. Г., Балашов К. В. Давня література: з полону стереотипів. Київ: Медієвіст, 2012.114 с. URL: https://www.medievist.org.ua/2014/11/blog-post_12.html (дата звернення: 22.11.2020).

9. Черкез І. Б. Іншомовна лексика латинського походження в українському епістолярії кінця XIX - початку XX ст. (до проблеми дослідження соціолекту інтелігенції). Наукові записки НаУКМА. Філологічні науки. Том 60. Київ : Видавничий дім «Києво-Могилянська академія», 2006. С. 42-49

10. Медієвіст : вебсайт. URL: http://www.medievist.org.uа (дата звернення: 22.11.2020).

11. PINAX : вебсайт. URL: http://www.pinax.com.ua (дата звернення: 22.11.2020). 
12. EPHEMERIS : вебсайт. URL: http://ephemeris.alcuinus.net/ (дата звернення: 22.11.2020).

13. CLE - Centrum Latinitatis Europae : вебсайт. URL: http://www.centrumlatinitatis.org/ (дата звернення: 22.11.2020).

\section{REFERENCES}

1. Balalaieva O. Iu. Proektuvannia elektronnykh posibnykiv z latynskoi movy dlia vyshchykh ahrarnykh navchalnykh zakladiv [Design of electronic textbooks in Latin for higher agricultural educational institutions]: dis....Cand. ped. Science: 13.00.10 / Kyiv. nat. un-t. bioresources. and used nature. Kyiv, 2016. 269 s. [ in Ukrainian].

2. Vakulyk I. I. Latynska mova: shliakhy pronyknennia u novi zakhidnoievropeiski movy [Latin: ways to penetrate into new Western European languages]. Scientific Bulletin of the National University of Life and Environmental Sciences of Ukraine. Philological Sciences Ser. 2016. Vyp. 257. S. 57-63 [in Ukrainian].

3. Hrytsenko S. P. Dynamika leksykonu ukrainskoi movy XVI-XVII st. [Dynamics of the lexicon of the Ukrainian language of the XVI - XVII centuries]: dis...Dr. Phil. Science: 10.02.01 / Kyiv. Taras Shevchenko National University. Kyiv, 2018. 1151 s. [ in Ukrainian].

4. Klimchuk H. P. Leksyka latynskoho pokhodzhennia v publitsystytsi M. Hrushevskoho [Vocabulary of Latin origin in the journalism of M. Hrushevsky]. Philological Studies: Scientific Bulletin of Kryvyi Rih State Pedagogical University. 2010. t. 4. S. 84-97 [ in Ukrainian].

5. Myronova V. M. Latyna yak dyplomatychna mova ukrainskoi elity XVI-XVII st. [Latin as a diplomatic language of the Ukrainian elite of the XVI-XVII centuries]. Studia Linguistica. 2009. Vyp. 3. S. 200-204 [ in Ukrainian].

6. Pankiv U. L. Istorychni dzherela ukrainskykh leksychnykh latynizmiv. [Historical sources of Ukrainian lexical Latinisms]. Studia Linguistica. 2011. Vyp. 5. S. 386-391 [ in Ukrainian].

7. Simonok V. P. Zapozychena leksyka v ukrainskii movnii kartyni svitu [Borrowed vocabulary in the Ukrainian language picture of the world]. Scientific Bulletin of the International Humanities University. Ser. Philology. 2014. №8, t. 2. S. 250-254 [in Ukrainian].

8. Shevchenko-Savchynska L., Balashov K. Davnia literatura: z polonu stereotypiv [Ancient literature: from the captivity of stereotypes]. Kyiv: Medievist, 2012. 114 p. [ in Ukrainian]. URL: https://www.medievist.org.ua/2014/11/blog-post_12. html (appeal date 22.11.2020)

9. Cherkez I. B. Inshomovna leksyka latynskoho pokhodzhennia v ukrainskomu epistoliarii kintsia XIX - pochatku $\mathrm{XX}$ st. (do problemy doslidzhennia sotsiolektu intelihentsii). [Foreign language vocabulary of Latin origin in the Ukrainian epistolary of the late XIX-early XX centuries. (to the problem of studying the sociolect of the intelligentsia)]. Scientific notes of NaUKMA. Philological sciences. Tom 60. K.: Publishing House "Kyiv-Mohyla Academy", 2006. S. $42-49$ [in Ukrainian].

10. URL: http://www.medievist.org.ua (appeal date 22.11.2020)

11. URL:http://www.pinax.om.ua (appeal date 22.11.2020)

12. URL: http://ephemeris.alcuinus.net/ (appeal date 22.11.2020)

13. URL: http://www.centrumlatinitatis.org/ (appeal date 22.11.2020) 